\title{
Perkembangan Kesenian Beluk di Desa Ciapus Banjaran
}

\author{
Muhammad Shidiq ${ }^{1}$ dan Bangbang M Rizki ${ }^{2}$ \\ Institus Seni Budaya Indonesia (ISBI) Bandung;; SMP Negeri 25 Bandung ${ }^{2}$ \\ Jalan Buah Batu No. 212, Cijagra, Kec. Lengkong, Kota Bandung, 40265'; Jln. Bukit Raya no. \\ 90, Ciumbuleuit, Kec. Cidadap, Kota Bandung, $40142^{2}$ \\ shidiq_muhammad17@yahoo.com 0821275474691; rizkibangbang@gmail.com 081802105946²
}

\begin{abstract}
Beluk is an art that originated from the habit of cultivators in ancient times who used a high and crooked voice to communicate and to be heard from a distance. This Beluk art will be the focus of elaboration in this paper. The method used to explain this art is descriptive qualitative, in which the author will explain how this art is performed in people's lives in Ciapus Village, Banjaran. The method used in this research is descriptive qualitative. Research data obtained from interviews and direct observations in the field. Beluk art is an art created by human culture for the need to communicate in ancient times. This art was born on the initiative of residents who need to communicate with each other when they are farming or farming.
\end{abstract}

Keywords: Beluk, Ciapus Village, Banjaran, Arts.

\begin{abstract}
ABSTRAK
Beluk merupakan kesenian yang bermula dari kebiasaan masyarakat peladang pada zaman dahulu yang menggunakan suara tinggi dan meliuk untuk berkomunikasi dan agar dapat terdengar dari kejauhan. Kesenian Beluk inilah yang akan menjadi fokus penjabaran dalam tulisan ini. Metode yang digunakan untuk menjelaskan kesenian ini adalah dengan kualitatif deskriptif, yang mana penulis akan menjelaskan bagaimana kesenian ini dipertunjukan dalam kehidupan masyarakat di Desa Ciapus, Banjaran. Metode yang digunakan dalam penelitian ini adalah kualitatif deskriptif. Data penelitian diperoleh dari wawancara serta pengematan langsung di lapangan. Kesenian Beluk merupakan kesenian hasil karya budaya manusia akan kebutuhan berkomunikasi pada zaman dahulu. Kesenian ini lahir atas inisiatif warga yang butuh saling berkomunikasi kala sedang bertani atau berladang.
\end{abstract}

Kata Kunci: Beluk, Desa Ciapus, Banjaran, Kesenian.

\section{PENDAHULUAN}

Rekam jejak sejarah manusia selalu diikuti dengan perkembangan kebudayaan. Manusia adalah satu-satunya mahluk hidup yang dalam perjalanannya selalu menciptakan kebudayaan-kebudayaan baru. Koentjaraningrat (2015, hlm. 144) mengungkapkan bahwa "kebudayaan merupakan keseluruhan sistem gagasan, tindakan, dan hasil karya milik manusia yang didapat dari hasil belajar". Dengan kata lain, kebudayaan merupakan bukti bahwa manusia merupakan mahluk dengan pemikiran yang kompleks dan lebih sempurna dari mahluk lainnya.

Berbicara tentang kebudayaan, melihat dari rekam manusia yang telah ada dan hidup sejak ribuan tahun, pasti sudah banyak 
kebudayaan yang lahir, hidup, dan bahkan mungkin mati tergerus zaman. Namun demikian, bukan mustahil bahwa kebudayaan yang telah berusia ribuan tahun tersebut ditemukan, bahkan dihidupkan kembali. Hal tersebut disebabkan oleh pada dasarnya kebudayaan yang ada sejak dahulu hilang karena sudah tidak banyak lagi orang yang mempraktikkannya di kehidupan sehari-hari.

Jika dikaji kembali, sebenarnya kebudayaan-kebudayaan yang ada atau yang pernah ada merupakan sebuah kekayaan tersendiri bagi sejarah umat manusia. Terlepas dari bagaimana kebudayaan itu sendiri, mungkin melenceng dengan nilai norma dunia baru atau sulit dipraktikkan pada era modern ini, manusia baiknya tidak pernah melupakan kebudayaan yang pernah ada tersebut.

Koentjaraningrat (2015, hlm. 165) menyatakan bahwa kebudayaan terdiri atas tujuh unsur yang disebut dengan kebudayaan universal, unsur tersebut meliputi: bahasa, sistem pengetahuan, organisasi sosial, sistem peralatan hidup dan teknologi, sistem mata pencaharian hidup, sistem religi, dan kesenian. Terkait dengan seni sendiri Indrawati (2020, hlm. 556) menyatakan bahwa Seni adalah salah satu dari perangkat simbolik pengungkap perasaan atau simbol ekspresif yang muncul dari dalam diri manusia. Berdasarkan kedua pernyataan tersebut bisa disimpulkan bahwa kebudayaan (yang salah satunya adalah kesenian) merupakan bagian dari sebuah perangkat atau alat untuk menunjukan ekspresi manusia. Lebih lagi, bisa disimpulkan keseluruhan perihal kebudayaan bisa dinyatakan sebagai alat untuk menyatakan eksistensi manusia itu sendiri.
Oleh karena hal tersebut, penulis mencoba untuk berpartisipasi dalam "perekaman" kebudayaan masa lalu yang perlu ditegaskan ulang dalam catatan sejarah kehidupan manusia. Dalam tulisan ini, penulis akan mendeskripsikan sebuah kebudayaan yang dinamakan Beluk.

Soepandi (1985, hlm. 23) menyatakan bahwa seni Beluk merupakan bentuk seni suara bebas dengan pupuh sebagai sumber rumpaka yang banyak dinyanyikan dengan nada yang tinggi. Selain itu, menurut Aep Yanyan (Praktisi Beluk, wawancara Mei 2019) Beluk secara bahasa memiliki arti "Celuk" atau memanggil. Hal ini berdasarkan kebiasaan masyarakat peladang pada zaman dahulu yang menggunakan suara tinggi dan meliuk untuk berkomunikasi dan agar dapat terdengar dari kejauhan.

Kesenian ini pada awalnya, hanya dijadikan sebagai cara berkomunikasi dan seni kalangenan atau seni yang menghibur diri sendiri. Seiring dengan perkembangan dan kebutuhan masyarakatnya, akhirnya seni ini digunakan untuk fungsi ritual, religi, dan juga hiburan bagi masyarakat pendukungnya. Seni Beluk biasanya digelar pada malam hari bahkan sampai semalam suntuk.

Kesenian Beluk inilah yang akan menjadi fokus penjabaran dalam tulisan ini. Metode yang digunakan untuk menjelaskan kesenian ini adalah dengan kualitatif deskriptif, yang mana penulis akan menjelaskan bagaimana kesenian ini dipertunjukan dalam kehidupan masyarakat di Desa Ciapus, Banjaran.

Penelitian ini bertujuan untuk menjelaskan bagaimana kesenian Beluk dipraktikkan dalam kehidupan masyarakat. 
Dengan demikian penulis berharap bisa memberikan pengatuan baru mengenai kesenian yang sedianya telah lama diciptakan dan hidup di kehidupan manusia.

\section{METODE}

Metodeyang digunakan dalam penelitian ini adalah kualitatif deskriptif. I Made Wirartha (2006, hlm. 155) menyatakan bahwa metode analisis deskriptif kualitatif adalah menganalisis, menggambarkan, dan meringkas berbagai kondisi, situasi dari berbagai data yang dikumpulkan berupa hasil wawacara atau pengamatan mengenai masalah yang diteliti yang terjadi di lapangan.

Dengan kata lain, di dalam artikel ini akan dijelaskan bagaimana kesenian Beluk yang berada di Desa Ciapus, Banjaran. Penjelasan tersebut diambil dari berbagai sudut pandang dan berdasarkan data di lapangan melalui pengamatan maupun hasil wawancara.

Penelitian dilakukan langsung di tempat kesenian Beluk dilakukan, yaitu di Desa Ciapus, Banjaran, Jawa Barat.

\section{HASIL DAN PEMBAHASAN}

Desa Ciapus adalah desa induk yang ada sejak tahun 1825 M. Berdasarkan sejarah, Ciapus bermakna dikuburkannya alat (perkakas) perang karena pada zaman kerajaan Mataram, pejabat seksi peralatan atau disebut juga dengan ngabehi pada masa itu melakukan pelarian hingga mencapai di Ciapus sampai akhir hayatnya menetap di sana.

Desan Ciapus sendiri mengalami pemekaran wilayah. Pemekaran tersebut membuat Desa Ciapus menjadi dua desa yaitu Desa Ciapus sendiri dengan Desa Mekarjaya. Desa ini memiliki luas wilayah 288,242 Ha, yang terbagi ke dalam empat dusun. Keempat dusun tersebut memiliki tipografi wilayah memanjang dari utara (Desa Banjaran) ke selatan (Desa Mekarjaya). Secara geografis, wilayah Ciapus masih kental dengan area pesawahan. Penduduk yang bermukim pada saat ini merupakan pendatang, dengan mayoritas mata pencaharian sebagai pedagang.

Hingga saat ini Desa Ciapus telah mengalami perkembangan yang pesat. Namun demikian, perkembangan yang dialami desa ini tidak disertai dengan pelestarian banyak kesenian tradisi budayanya, salah satunya adalah Beluk. Oleh sebab itu, peneliti berharap dengan mengangkat Beluk sebagai objek pembahasan dan penelitian, bisa mengangkat lagi kesenian ini untuk diketahui dan lebih lanjut dilestarikan oleh generasi berikutnya.

Berdasarkan informasi yang didapatkan dari narasumber yang merupakan praktisi beluk itu sendiri ditemukan bahwa eksistensi beluk mengalami pasang surut. Lahir, hidup, dan berkembang di lingkungan masyarakat di tanah Sunda. Namun demikian, kesenian ini selalu menjadi bagian dari kehidupan masyarakat di lingkungan sekitar Desa Ciapus karena pada dasarnya masyarakat sendirilah yang menghidupkan kesenian ini pada awalnya. Sejalan dengan pernyataan Selo Soemardjan dan Soelaeman Soemardi (dalam Soekanto, 1995, hlm. 189) yang menyatakan bahwa "semua hasil karya, rasa, dan cipta masyarakat. Dengan kata lain, semua yang 
diciptakan kelompok manusia (masyarakat) merupakan kebudayaan".

Selanjutnya kesenian ini diturunkan secara turun-temurun dari satu generasi ke generasi berikutnya. Mutakin dan Pasya (2002, hlm. 8) menuturkan "kebudayaan adalah suatu akumulasi pengalaman belajar, yang diturunkan dari satu generasi ke generasigenerasi berikutnya, dan didifusikan dari kelompok masyarakat yang satu ke kelompok masyarakat lainnya yang menempati berbagai wilayah di permukaan bumi". Dengan kata lain bahwa, tentu saja kesenian ini akan terus diwariskan secara turun temurun karena kesenian ini sudah menjadi bagian budaya dari Desa Ciapus, Banjaran.

Awalnya, Kesenian Beluk berfungsi sebagai media ritual dan dipertunjukkan pada acara yang dianggap sakral oleh warga desa. Namun dewasa ini, pelaksanaan kesenian ini mengalami transformasi fungsi, yang awalnya merupakan media ritual kemudian berubah menjadi media hiburan. Bentuk hiburannya sendiri bisa berupa hiburan untuk pribadi (hiburan untuk diri sendiri) maupun bagi warga yang menyaksikan dan mengapresiasi kesenian ini melalui acara-acara tertentu.

Berdasarkan wawancara dengan Pak Udin (Mei 2019) yang merupakan praktisi kesenian Beluk Desa Ciapus berusia 56 tahun pada saat wawancara dilakukan, kesenian Beluk ini jika diamati dari sudut pandang bahasa, berasal dari bahasa Sunda buhun (zaman dahulu) yaitu "caluk" yang berarti "ngageroan" (memanggil). Awalnya caluk digunakan orang tua pada zaman dahulu untuk memanggil anak-anaknya yang sedang bermain untuk menyuruhnya pulang.
Selain itu, kata caluk juga digunakan untuk memanggil sesama peladang yang sedang bekerja dengan jarak yang cukup jauh. Selain pengertian itu, caluk juga tercatat dalam istilah bahasa Sunda "Kaceluk ka awun-awun, Kakoncar ka janapria". Istilah ini berarti memanggil dengan suara tinggi, lantang, sehingga suara tersebut terdengar sampai jauh, cukup jauh untuk mencapai orang yang berada di tempat yang jauh dari orang yang memanggilnya.

Pada saat ini, caluk merupakan bahasa Sunda yang sudah sangat jarang digunakan. Bahkan, untuk generasi muda sekarang, kata ini sudah cukup asing di telinga mereka lebih lagi mengatahui artinya.

Awalnya kesenian Beluk lahir di masyarakat peladang atau petani. Mereka memanfaatkan caluk untuk berkomunikasi antara satu dengan yang lainnya dari jarak yang jauh. Hal ini dilakukan agar suara yang dihasilkan terdengar oleh orang yang dimaksudkan karena jarak antarsawah atau ladang mereka cukup jauh. Mereka saling bersuara atau saling menyeluk dengan menggunakan suara tinggi yang hampir terdengar ngagorowok atau berteriak untuk menyatakan mereka mendengar dan berada di dalam saung.

Soepandi (1985, hlm. 23) menyebutkan bahwa seni Beluk adalah salah satu bentuk seni suara bebas dengan pupuh sebagai sumber rumpaka yang banyak dinyanyikan dengan nada yang tinggi. Kesenian ini digolongkan ke dalam kategori seni vokal dengan menggunakan nada-nada yang tinggi tanpa penggunaan iringan waditra atau alat/instrumen musik. Musik sendiri bisa dijabarkan sebagai cabang seni yang 
membahas dan menetapkan berbagai suara ke dalam pola-pola yang dapat dimengerti dan dipahami manusia (Banoe, dalam Lestari, Jurnal Panggung, Vol. 30, No. 3, 2020). Oleh karena hal tersebut, kesenian ini memiliki ciri khasnya sendiri dibandingkan dengan seni vokal lainnya. Penyajian kesenian ini sendiri memanfaatkan teks cerita atau naskah yang dilantunkan selama pertunjukan berlangsung. Teks atau naskah ini berupa cerita dengan aturan pupuh dalam Sunda.

Sukanda (1984, hlm. 9) menuturkan bahwa Beluk berasal dari kata "meluk", yang artinya melagu menggunakan surupan atau nada dasar tinggi dengan ornamen yang meliuk, mengalun, dan meliku. Nada yang dihasilkan ini tinggi, meliuk, mengalun, dan meliku, digunakan para pemain Beluk saat mereka dalam kesunyian di tengah sawah, ladang, atau kebun untuk menandakan keberadaan orang tersebut dengan tujuan agar terdengar oleh orang lain. Apabila ada orang lain yang mendengarnya, lengkingan tersebut berfungsi sebagai komunikasi dan lengkingan tersebut akan dibalas dan saling bersahutan.

Pada awalnya, kesenian Beluk hanya memiliki fungsi-fungsi tertentu di tengah masyarakat yang memiliki kesenian ini. Dahulu, utamanya di daerah Ciapus, Banjaran, Beluk memiliki fungsi sebagai media hiburan bagi masyarakat. Kesenian ini sangat ditunggu-tunggu dan diapresiasi oleh masyarakat Banjaran pada saat itu karena di dalam kesenian ini, selalu berisi cerita yang disampaikan dalam bentuk dongeng. Belum majunya teknologi informasi dan sarana hiburan pada masa itu, menjadikan kesenian ini salah satu dari sedikit hiburan bagi masyarakat di desa tersebut. Pada zaman itu, budaya mendongeng adalah hal yang selalu dilakukan, baik oleh orangtua kepada anakanaknya maupun guru kepada muridnya. Budaya ini yang menjadikan beluk menjelma menjadi kesenian yang sangat disenangi dan sangat diapresiasi oleh masyarakat pada masa itu.

Selanjutnya sekitar tahun 1960-an di Desa Ciapus, Banjaran, kesenian Beluk mulai mengalami banyak transformasi dalam kaitannya dengan fungsi. Kesenian ini pada tahun tersebut mulai muncul dalam acara-acara ritual seperti syukuran 40 hari kelahiran bayi atau pada acara syukuran hasil panen yang masyarakat (karena pada masa itu masyarakat desa mayoritasnya masih berprofesi sebagai petani atau peladang). Seiring dengan perjalanan zaman, kesenian ini mengalami pergeseran/perkembangan nilai yang awalnya hanya dipentaskan dalam acara syukuran 40 hari kelahiran bayi dan syukuran hasil panen, kini kesenian ini banyak dijumpai dalam perayaan besar seperti HUT RI atau hari ulang tahun desa, juga perayaan khitanan atau pernikahan.

Kesenian Beluk selalu terikat dengan kisah yang dilantunkan di dalamnya. Kisah yang dimaksud adalah wawacan. Ruhaliah (2018, hlm. 10) menuturkan, wawacan merupakan cerita panjang (naratif), tetapi ada juga uraian (deskriptif) yang dituangkan dalam bentuk puisi Sunda atau pupuh. Pupuh sendiri merupakan sebuah kesatuan bentuk puisi yang memiliki ketentuan jumlah suku kata serta vokal akhir (rima) di setiap lariknya. Sejalan dengan Ruhaliah, Udin (56 tahun, praktisi Beluk Desa Ciapus, wawancara Mei 
2019) menyatakan juga bahwa jika diamati dari sudut pandang kebudayaannya, beluk merupakan hiburan berbentuk dongeng babad dan dongeng kesaktian yang dikisahkan melalui pupuh Sunda yang berjumlah 17 buah. Pupuh yang digunakan dalam wawacan sendiri berjumlah 17 buah dengan aturan penulisan yang berbeda mengikuti jumlah guru wilangan (suku kata) dan guru lagu (bunyi akhir kalimat/rima). Рupuh tersebut yaitu Kinanti, Sinom, Asmarandana, Dangdanggula, Mijil, Pangkur, Durma, Gurisa, Gambuh, Ladrang, Lambang, Maskumambang, Balakbak, Magatru, Pucung, Wirangrong, dan Jurudemung. Berdasarkan isinya, pada umumnya wawacan berkisah tentang mitologi, legenda, cerita rakyat, asal-usul terjadinya sesuatu atau suatu tempat, dan juga ada wawacan yang berkisah tentang doa, nasihat, dan pepatah.

Namun demikian, jika dilihat dari sejarah tulisannya, naskah beluk sendiri awalnya banyak ditulis dengan menggunakan huruf Arab Pegon (aksara Arab yang dimodifikasi untuk menuliskan bahasa Jawa) dengan memanfaatkan harupat dan tinta gosok. Hal ini disebabkan oleh karena pada zaman tersebut masih sedikit masyarakat yang mengenal aksara latin. Menurut pak Udin di dalam wawancara (Mei 2019), hal ini juga sama seperti penyebaran Islam oleh wali songo yang banyak mengenalkan tulisan Arab. Dongeng yang diceritakan dalam beluk sendiri, bisa dimainkan dengan cara di-rancag atau dibacakan biasa (membaca biasa tanpa nada) dengan sedikit ada tekanan-tekanan di katakata tertentu, namun bisa juga dibelukkeun atau diberi ornamen nada sesuai dengan kaidah ketentuan pupuh. Berdasarkan pemaparan

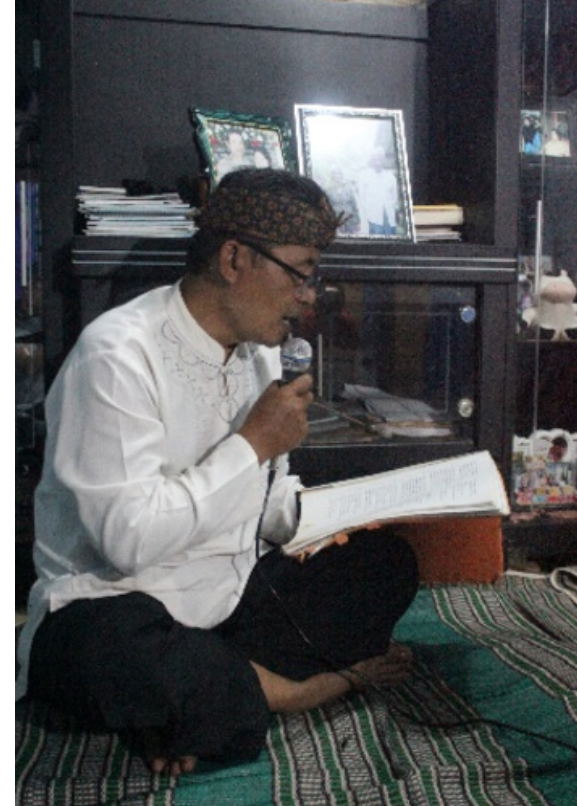

Gambar 1. Dalang Seni Beluk Mitra Sunda (Sumber: Dokumen Pribadi, 2019)

tersebut, dapat dibuat sebuah kesimpulan bahwa, kesenian beluk adalah kesenian yang mengedepankan seni suara. Lebih lagi, pemain beluk sudah tahu dan fasih dalam mengambil serta memilih nada yang mana, setelah juru ilo memberi umpan. Juru ilo atau yang biasa disebut anu ngilo adalah orang yang bertugas membacakan pupuh dan kemudian pupuh tersebut diulang dan ditambah oleh pemain beluk yang lain.

Dalam bentuk penyajiannya, beluk dimainkan oleh empat orang atau lebih dengan mengenakan baju atau busana khas Sunda berupa pangsi atau kampret yang dilengkapi dengan ikat kepala atau iket. Kesenian Beluk memiliki beberapa istilah dan pembagian tugas untuk para pemainnya, di antaranya adalah sebagai berikut.

a. Dalang

Dalang merupakan orang yang bertugas untuk menentukan cerita wawacan yang akan dipertunjukkan dalam kesenian Beluk. 


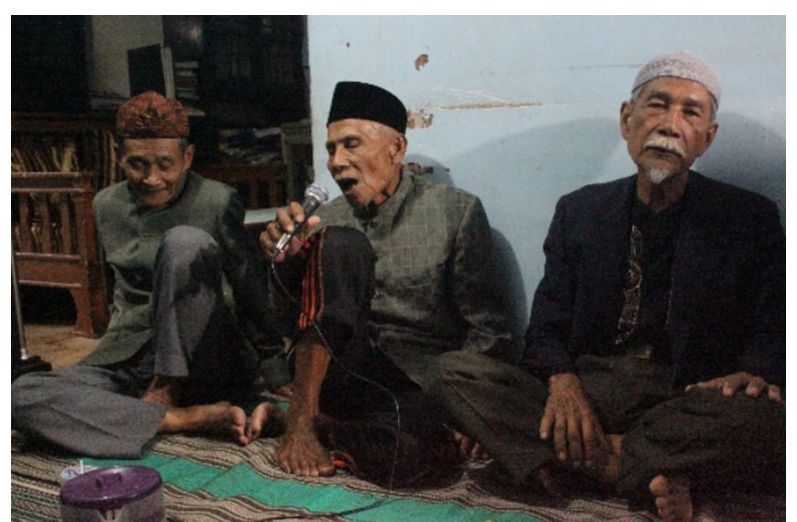

Gambar 2. Tukang Ngilo, Tukang Ngajual, dan Tukang Meuli/Naekkeun

(Sumber: Dokumen Pribadi, 2019)

b. Tukang ngilo

Tukang ngilo atau anu ngilo merupakan orang yang bertugas membacakan wawacan tanpa dinyanyikan/dilantunkan. Pemain ini memiliki fungsi yang sama dengan pembaca prolog dalam pementasan teater. Wawacan awal ini dibacakan perbaris dengan tempo yang sedang dan artikulasi yang jelas.

c. Tukang ngajual

Tukang ngajual merupakan orang yang menyanyikan bagian wawacan yang sebelumnya telah dibacakan oleh tukang ngilo, namun kali ini dengan menggunakan aturan-aturan pupuh. Namun demikian, pemain ini akan menyanyikannya tanpa ornamenornamen atau dengan kata lain hanya dengan nada dasar yang tidak terlalu tinggi dan tanpa improvisasi nada.

d. Tukang meuli

Tukang meuli merupakan pemain yang diberi tugas untuk melanjutkan nyanyian lagu yang sebelumnya telah disajikan oleh tukang ngajual.

e. Tukang naekkeun
Tukang naekkeun merupakan pemain beluk yang bertugas untuk melanjutkan nyanyian tukang meuli dengan menggunakan nada yang meliuk dan nada yang tinggi.

Sesuai dengan perannya masing-masing, para pemain kesenian Beluk bisa menyajikan cerita yang dibawakan dengan cara bergiliran. Oleh sebab kesenian ini ditampilkan dalam waktu semalaman, dikhawatirkan jika salah satu pemain selalu membacakan (memerankan) bagian yang sama, kondisi suara dan kesehatan pemain Beluk akan terganggu (karena kesenian ini membutuhkan nada yang sangat tinggi). Kesenian Beluk sendiri biasanya ditampilkan pada saat malam hari, mulai dari pukul 08.00 hingga dini hari. Lebih lagi, jika cerita wawacan yang dibawakan terlalu panjang, bisa jadi kesenian ini ditampilkan sampai keesokan harinya tergantung persetujuan dari yang memiliki hajat.

Kesenian Beluk biasanya dipentaskan dengan tidak menggunakan panggung seperti kesenian tradisional lainnya yang menggunakan panggung atau level. Kesenian ini digelar di tengah rumah atau halaman dengan hanya beralaskan karpet atau tikar. Pemain Beluk diposisikan duduk bersila dengan berjajar atau melingkar bersama keluarga yang mengundang pemain beluk atau yang menggelar acara/hajat dan ada juga tokoh masyarakat di daerah tersebut. Kemudian, di tengahnya disediakan sesajen atau sesaji, berupa makanan dan minuman, serta beberapa hasil panen.

Secara teknis, pementasan kesenian Beluk di Desa Ciapus, Banjaran masih berdasarkan 
pakem atau aturan yang telah diwariskan turun-temurun. Teknis pementasan kesenian Beluk tersebut adalah sebagai berikut.

a. Pembukaan

Sebelum pementasan Beluk dimulai, sarana yang diperlukan untuk keperluan pertunjukan telah disiapkan terlebihdahulusemuanya.Sarana-sarana tersebut mulai dari naskah wawacan, sesajen, dan yang lainnya. Kesenian ini pada acara-acara seperti syukuran 40 harian, syukuran panen, dan beberapa acara sakral lainnya dimulai dengan sambutan-sambutan oleh pupuhu atau pemimpin rombongan kesenian Beluk. Selanjutnya setelah itu, tokoh masyarakat atau tuan rumah (orang/ keluarga yang menyelenggarakan acara) juga memberikan sambutan. Tujuan dari sambutan-sambutan tersebut adalah untuk memberikan informasi kepada masyarakat tentang acara dan memohon izin tentang penyelenggaraan kesenian ini. Selanjutnya, acara ini dilanjutkan dengan pembacaan doa oleh pawang atau sesepuh dengan tujuan agar penyelenggaraan kesenian Beluk hari tersebut berjalan lancar dari awal sampai akhir.

b. Pelaksanaan

Segera setelah semua persiapan pertunjukan dipersiapkan, maka barulah pertunjukan Beluk bisa dimulai. Pertunjukan ini dimulai dengan pembacaan prolog yang dilakukan oleh Juru Ilo untuk menggambarkan terkait cerita/kisah wawacan apa yang akan dibawakan oleh para pemain Beluk dalam pergelaran hari itu. Selanjutnya, setelah prolog oleh Juru Ilo dilantunkan menggunakan nada yang meliuk oleh Tukang Ngajual berdasarkan dengan aturan pupuhnya, kemudian disambung oleh Tukang Meuli dengan nada-nada tinggi, suara yang melengking, dan tentunya meliuk-. Begitulah terus acara berlangsung sambung-menyambung bergiliran sampai cerita wawacan selesai.

c. Penutupan

Pada akhir pergelaran kesenian Beluk, Tukang Ilo memberikan kesimpulan cerita yang bekaitan dengan isi, amanat, dan nasihat-nasihat yang ada di dalam wawacan yang dibawakan. Setelah itu, orang yang memimpin kesenian Beluk menutup acara ini dengan permohonan maaf dan ucapan terima kasih kepada seluruh hadirin yang datang dan menonton serta mengapresiasi pertunjukan dari awal hingga akhir. Selanjutnya, acara diakhiri dengan pembacaan doa oleh tokoh masyarakat setempat.

Kesenian Beluk di Desa Ciapus, Banjaran dewasa ini masih dimainkan oleh generasi keempat keluarga Bapak Oyib Sudjana. Beliau merupakan pendiri dari sanggar seni Beluk Mitra Sunda. Menurut praktisi beluk yang telah peneliti jumpai di desa tersebut, beluk memiliki dua versi. Versi yang pertama yaitu adalah beluk yang hidup dan berkembang di Rancakalong dan beluk yang ada di Ciapus, Banjaran. Versi tersebut didasari oleh di mana kesenian tersebut hidup dan berkembang. Beluk yang berkembang di dua daerah tersebut sendiri memiliki ciri-ciri dan perbedaannya 
02 RW 02 Desa Ciapus, Kecamatan Banjaran.

masing-masing. Ciri dan perbedaan tersebut bisa diidentifikasi dari nada yang dimainkan dan diperdengarkan oleh para pemainnya. Beluk versi Desa Rancakalong, memiliki ciri yaitu menggunakan nada yang tinggi dan nadanya terus menerus naik dan tidak didasari dengan aturan pupuh. Lain halnya dengan beluk dari Desa Ciapus, beluk dari desa ini ketat dan patuh terhadap aturan 17 pupuh dan menggunakan nada yang tidak terlalu tinggi, dengan tujuan agar cerita yang dibawakan dapat disampaikan dengan jelas kepada hadirin (masyarakat yang hadir untuk menyaksikan pertunjukan).

Seiring perkembangan dari kesenian ini, utamanya beluk yang ada di Ciapus Banjaran, pementasan beluk pada zaman dahulu hanya diselenggarakan untuk acara-acara tertentu saja. Pertunjukkan ini di Ciapus, biasa diselenggarakan dalam acara syukuran melahirkan, panen, ataupun khitanan. Keberadaan beluk pada acara tersebut sangat dinantikan dan dinikmati masyarakat sekitar. Hal ini disebabkan oleh karena, mereka menganggap kesenian ini sebagai salah satu hiburan ditengah kehidupan mereka di desa. Pada masa saat kesenian ini berkembang cukup pesat, di Desa Ciapus ada puluhan grup kesenian beluk. Namun demikian, dewasa ini dari puluhan grup tersebut, sayangnya kini hanya satu grup yang bertahan. Kesenian beluk yang merupakan warisan turun-temurun semakin lama semakin ditinggalkan dan dilupakan. Satu-satunya grup yang masih melestarikan beluk tersebut merupakan grup yang dipimpin oleh Bapak Aep Yanyan Cardiana, berusia 54 tahun, dan beliau bermukim di alamat $\mathrm{Kp}$. Ciapus RT
Menurut penuturan Beliau, keluarganya telah menjadi praktisi beluk sejak generasi pertama dan Kini Pa Aep adalah generasi ke-4, namun sayangnya belum ada penerusnya lagi.

Berdasarkan penuturan Pak Aep (54 tahun, praktisi Beluk Desa Ciapus, wawancara Mei 2019), pada tahun 70-an, terdapat sangat banyak grup beluk yang berbasis di Banjaran. Namun, grup-grup tersebut kini hanya bersisa satu grup yaitu grup beluk miliknya yang bernama "Mitra Sunda". Masa kejayaan beluk di Banjaran, berada pada tahun 1960-1970 dan selalu digunakan sebagai media silaturahmi dan juga media hiburan antara warga masyarakat. Menurut penuturan Beliau, "Mitra Sunda" adalah satu-satunya grup beluk yang tersisa di Desa Ciapus dan dewasa ini pertunjukkannya pun hanya sebatas untuk mengenalkan kepada masyarakat tentang kesenian ini dan tanpa adanya cerita yang utuh. Beberapa kali grup beluk "Mitra Sunda" diundang ke beberapa universitas, kementrian, ataupun stasiun televisi. Namun demikian, sayangnya mereka tidak menyajikan kesenian tersebut secara utuh. Dalam pergelarannya (ketika diundang oleh stasiun televisi, universitas, atau kementrian), naskah beluk diringkas sesuai permintaan. Pementasan kesenian beluk yang biasanya digelar semalam suntuk, kini hanya ditampilkan selama lima belas menit sampai satu jam saja.

Perbedaan mencolok lainnya, dari pergelaran semestinya dengan pergelaran tersebut adalah, selain waktu pementasan yang kini lebih sering diringkas, tempat dipentaskannya pertunjukkan beluk pun kini bisa di mana saja. Pada awalnya, kesenian ini 
biasanya hanya dipentaskan di rumah dari orang yang memiliki acara, kini bisa juga dipentaskan di atas panggung.

Penonton atau partisipan (hadirin) dalam kesenian beluk ini hampir seluruhnya adalah keluarga dan kerabat dari tuan rumah yang memiliki tempat dan acara dipentaskannya kesenian beluk. Selama pementasan ini berlangsung, penonton dan hadirin duduk dengan khidmat untuk mendengarkan cerita yang disajikan oleh para pemain beluk. Penonton memosisikan diri mereka untuk duduk melingkar dan bergabung serta berbaur dengan pemain beluk. Sesekali di tengah pementasan, ketika ada perpindahan pupuh, para pemain beluk menyapa penonton dan hadirin, lalu penonton pun memberikan tepuk tangan sebagai apresiasi seraya menjawab sapaan pemain beluk tersebut. Pada akhir pertunjukan, pemain beluk menyalami penonton satu persatu sambil meminta maaf kepada mereka apabila ada salah penyampaian cerita atau nada yang sumbang ketika naskah dilantunkan.

Kesenian Beluk sendiri biasa dipentaskan dengan tidak menggunakan panggung. Berbeda dengan kesenian tradisional lainnya yang menggunakan panggung atau level. Kesenian ini digelar di tengah rumah atau halaman rumah beralaskan karpet atau tikar. Pemain Beluk duduk bersila secara berjajar atau melingkar bersama keluarga yang mengundang atau yang mempunyai hajat, dan juga tokoh masyarakat di daerah tersebut. Dengan demikian, interaksi pemain kesenian ini dengan hadirin bisa dengan mudah dilakukan.

\section{SIMPULAN}

Kesenian Beluk merupakan kesenian hasil karya budaya manusia akan kebutuhan berkomunikasi pada zaman dahulu. Kesenian ini lahir atas inisiatif warga yang butuh saling berkomunikasi kala sedang bertani atau berladang. Jauhnya jarak antara petani atau peladang yang satu dengan yang lainnya membuat masyarakat yang perlu melakukan komunikasi dengan satu sama lain, mencari cara agar komunikasi itu tetap bisa berlangsung. Oleh karena, pada masa tersebut, teknologi komunikasi belum secanggih sekarang, maka masyarakatpun memanfaatkan apa yang ada untuk bisa berkomunkasi. Pada akhirnya terciptalah kesenian beluk dengan melalui banyak waktu dan dimatangkan oleh waktu juga.

Kesenian beluk sendiri merupakan seni suara yang dimainkan/dipentaskan oleh sekelompok orang dengan perannya masingmasing. Setiap peran memiliki kontribusinya sendiri dalam pementasan kesenian ini. Pementasan beluk biasanya merupakan pementasan berbasis teks/naskah cerita dari cerita-cerita rakyat Sunda. Kesenian ini biasanya dipentaskan semalam suntuk atau bahkan lebih, tergantung panjangnya cerita atau kesepakatan tuan rumah dengan pemain kesenian ini. Pada awalnya, kesenian ini dipentaskan pada acara yang dianggap cukup sakral seperti upacara 40 kelahiran bayi atau syukuran hasil panen. Namun demikian, sekarang kesenian ini lebih banyak dipentaskan dalam acara-acara yang lebih luas seperti khitanan dsb. Bahkan dewasa ini, pemain kesenian ini dipanggil oleh pemerintah sebagai bentuk demonstrasi kesenian beluk 
yang masih hidup di tengah masyarakat pengapresiasi dan pemeliharanya.

Desa Ciapus, Banjaran menjadi salah satu "rumah" di mana kesenian ini masih hidup di antara masyarakatnya. Kesenian Beluk di desa ini dipentaskan dalam acaraacara tertentu sesuai panggilan tuan rumah acara. Meskipun pada awalnya, kesenian ini merupakan bentuk komunikasi yang unik, namun seiring berjalannya waktu, beluk menjadi pertunjukan/hiburan tersendiri bagi pengapresiasinya.

\section{DAFTAR PUSTAKA}

Irdawati. (2020). Fungsi dan Makna Simbolis Tari Toga di Kerajaan Siguntur Pulau Punjung Sumatera Barat. Jurnal Pangoung, Vol. 30, No. 4.

Koentjaraningrat. (1987). Sejarah Teori Antropologi. Jakarta: UI Press.

Koentjaraningrat. (2015). Pengantar Ilmu Antropologi. Jakarta: Rineka Cipta.

Lestari, Dewi Tika, (2020). Membangun Harmoni Sosial melalui Musik dalam Ekspresi Budaya Orang Basudara di Maluku. Jurnal Panggung, Vol. 30, No. 3.

Mutakin, Awan, Pasya, Kamil G. (2002). Geografi Budaya. Bandung: Penerbt Suci Press.

Ruhaliah. (2018). Wawacan: Sebuah Genre Sastra Sunda. Bandung: PT. Dunia Pustaka Jaya.

Soekanto, Soerjono. (1995). Sosiologi Suatu Pengantar. Jakarta: Rajawali Press.

Soepandi, A. (1985). Lagu Pupuh Pengetahuan dan Notasinya. Bandung: Pustaka Buana.

Sukanda, E. (1984). Tembang Sunda Cianjuran Sekitar Pembentukan dan Perkembangan. Bandung: Tarate.
Wirartha, I Made. (2006). Pedoman Penulisan Usulan Penelitian, Skripsi dan Tesis. Yogyakarta: Andi.

\section{Narasumber}

Udin (56 tahun) Praktisi Kesenian Beluk Desa Ciapus. Wawancara, Mei 2019.

Aep Yanyan Cardiana (54 tahun) Praktisi Kesenian Beluk Desa Ciapus. Wawancara Mei 2019. 